\title{
EFFECT OF BUERGER ALLEN EXERCISE ON LOWER LIMB PERFUSION AMONG PATIENTS WITH TYPE 2 DIABETES MELLITUS \\ ${ }^{1}$ Walaa El-khanany Zahran, ${ }^{2}$ Amira Ahmed Hassanen, ${ }^{3}$ Madiha Hassan Nabih and ${ }^{4}$ Fady Azmy Kyrillos. \\ 1,2,3Medical-Surgical Nursing Department, Faculty of Nursing-Mansoura University 4 Internal Medicine Department, Faculty of Medicine - Mansoura University E-mail of corresponding author: w.zahran1@yahoo.com.
}

\begin{abstract}
:
Diabetes related lower extremity complication increase the risk for amputation which include peripheral neuropathy, peripheral vascular disease, and infection. Peripheral arterial disease is estimated to be 2 to 4 times more common in persons with diabetes than in others - Buerger Allen exercise intended to improve feet, legs circulation and relieve the symptoms in patients with lower limbs arterial insufficiency. Therefore, the aim of the study, evaluate the effect of Burger Allen exercise on lower limb perfusion in patients with type 2 diabetes mellitus. Method and sample, Quasi-experimental research design was conducted in the diabetic and endocrine ward and diabetic foot clinic in SpecializedMedical Hospital, at Mansoura University. The sample of this study composed of 48 adult patients with type 2 Diabetes who attend the diabetic ward and diabetic foot clinic in Specialized-Medical Hospital throughout six months. Patients randomly assigned into two matched groups; study group (group A) and control group (group B). Results, indicates significant improvement into patients lower extremity perfusion by using Ankle Brachial Index ( ABI) scale after performance of Buerger Allen exercise and at the same time it helped to improve the vascularity and thus promotes the wound healing process. Conclusion, positive effect of Buerger Allen exercise on diabetic patients lower extremity perfusion.
\end{abstract}

Key words: Buerger Allen Exercise, Lower Limb perfusion, Type 2 Diabetes Mellitus

\section{Introduction:}

Diabetes is one of the major global health emergencies of the $21 \mathrm{st}$ century. The prevalence of diabetes mellitus is increasing rapidly because of population ageing, urbanization and lifestyle changes $^{(1,2)}$.According to WHO This number of people with diabetes has risen to 422 million in 2014, and expected to rise to 552 million (or 1 in 10 adults) by 2030, which equal to 3 new cases per second $(\mathbf{3}, \mathbf{4})$. The number of diabetic patients in the Middle East and North Africa ( MENA ) Region is more than 35.4 million and expected to rise by 2040 to 72.1 million. In Egypt, there are more than 7.8 million cases of diabetes ${ }^{(2)}$. Feet problems considered among the most serious complications of diabetes mellitus (5). Diabetes associated lower extremity complications like peripheral arterial disease (PAD), peripheral neuropathy, foot ulceration or lower extremity amputations (LEA), are emerging as a public health concern which likely to occur twice in diabetics than non-diabetics ${ }^{(6)}$. Peripheral arterial disease (PAD) is a chronic atherosclerotic process that causes narrowing of the peripheral blood vessels, predominantly of the lower limbs. Patients with diabetes have 4 fold increased risk of developing PAD ${ }^{(7)}$. Buerger Allen exercise is a system of exercises for 
arterial insufficiency of lower limbs to improve circulation to the feet and legs. This exercise produce gravitational changes in positions which aid in increasing blood flow rate, removal of stagnant blood and create collateral circulation to the ischemic area ${ }^{(8,9)}$. Buerger exercise is an ideal and noninvasive physical therapy for patients with diabetes combined with PAD as it is an easy to learn, low cost, and low risk physical activity ${ }^{(10)}$.

1. The study aim: The aim of the study was to evaluate the effect of Burger Allen exercise on lower limb perfusion of patients with type 2 diabetes mellitus.

\section{Research hypothesis:}

H1: There will be significant association between Buerger Allen exercise and lower limb perfusion of patients with type 2 diabetes mellitus.

\section{Subjects \& method :}

3.1 - Research Design: Quasi experimental research design was utilized in this study.

3.2 - Setting: This Study was conducted at diabetic and endocrine ward and diabetic foot clinic in SpecializedMedical Hospital, at Mansoura University.

3.3 Participants: Purposive sample of 48 adult patients with type 2 Diabetes who attend the diabetic and endocrine ward and diabetic foot clinic in Specialized-Medical Hospital, at Mansoura University throughout six months. Patients randomly assigned into two matched groups; study group (group A) and control group (group B). The study group involved patients who performed Burger Allen exercise in addition to routine care while the control group involved patients receiving only routine care. Study included adult patients of both sexes with type 2 Diabetes and ankle
Brachial Index ( ABI) : ranged from $0.4-0.9$ and excluded patients with ABI : less than 0.4,Wagner grade $(3,4,5)$ classification of diabetic foot, deep vein thrombosis, unstable coronary heart diseases, acutely ill patient, chronic renal failure, chronic liver disease and patients with no palpable extremity pulse.

4.4 Tools: Two tools had used in this study as the following :

4.4.1- Tool I:Patient's Health Relevant Information Sheet. This tool was developed by the researcher based on literature review to collect the required base line data and consists of two parts: Part 1: socio-demographic data sheet: This part was used to collect personal data of patients as : age, gender, marital status, educational level ,occupation and type of job.

Part 2: Patient's Health status :This part was used to assess patient current diagnosis, length of time since diagnosis, presence of diabetic foot ulcer, other health problems, past history, family history, dietary pattern ........, etc.

4.4.2- Tool II: Tissue perfusion assessment: Ankle Brachial Index (ABI). The ABI is used to assess tissues perfusion of lower limbs and calculated by dividing the systolic blood pressure at the ankle (Posterior tibial or Dorsalis Pedis) by the systolic blood pressures in the arm (Brachial) by using sphygmomanometer $^{(\mathbf{1 1}, \mathbf{1 2})}$.

$\mathrm{ABI}=$ Highest ankle systolic pressure

Highest brachial arm pressure

Scoring system:

\begin{tabular}{|c|c|}
\hline Above 0.9 & Normal \\
\hline $0.71-0.90$ & Mild Obstruction \\
\hline $0.41-0.70$ & Moderate Obstruction \\
\hline $0.0-0.40$ & Severe Obstruction \\
\hline
\end{tabular}


EFFECT OF BUERGER ALLEN EXERCISE etc...

4.5- Methods:

- The researcher obtained the required permissions from the Research Ethics Committee of Nursing faculty, Mansoura University.

- A verbal consent was obtained from patients who participated in the study after clear explanation of the aim and the nature of the study.

- Tools tested for content validity by seven experts from both field of medicine and nursing. Faculty of nursing -Mansoura university (5 members), and medical specialist (2members) in the Specialized-Medical Hospital, at Mansoura University. The required modifications were done.

- A pilot study was carried out on 10 patients, before data collection to test the clarity, feasibility, applicability, reliability. The tools was modified according to results of pilot study. These ten patients were excluded from the study.

- Data collection extended over a periods of six months

- Filed work: The field of working included the following phases:

A. Assessment phase: Every patient was interviewed individually to collect the necessary data after giving him a brief idea about the aim of the study using tool I, part(1).The researcher started by assessing patients on day (1) before intervention, assessment was done using tool I, part (2) and tool II (ABI) scale .ABI was done by using standard manual sphygmomanometer and standard hand Doppler.

Ankle brachial pressure index measured by blood pressure cuff tied on upper arm, palpate the brachial pulse then applying gel, place the Doppler and inflate the cuff about $20-30 \mathrm{mmHg}$ after pulse is not audible and then deflate slowly and mark the first heard pulse as the systolic blood pressure and repeat for the other arm and the highest was used. Blood pressure cuff tied on $2.5 \mathrm{~cm}$ above the malleolus, measurement was made for both the dorsalis pedis(DP) and posterior tibial(PT)and the highest value was used. Then divided the higher systolic pressures of DP or PT pulse for each ankle by the higher of the two upper extremity brachial systolic pressures to obtain the ABI for each of the lower limbs ${ }^{(13)}$.

\section{B. Implementation phase:}

The researcher instructed to the patients the importance of Buerger Allen exercise in improving perfusion of lower limbs and preventing further complication related to circulation ,then taught Buerger Allen exercises to the patient using colored booklet after assessment followed by return demonstration from the patient and patients were instructed to perform it at least two sessions per day.

- Buerger Allen exercise consisted of two to three sessions a day according to patient tolerance, every session consisted of 3 phases. In first phase the patient Lie flat with legs elevated above the level of the heart to a 45 to 90 degree angle until blanching occurred (about 2 minutes).

- Then sit on edge of bed and lower the legs with no pressure against the back of the knees to fill the vessels and exercise feet by plantarflexion, dorsiflexion ,internal and external rotation until the legs are pink (about 5 minutes) $(\mathbf{1 0})$.

- Finally, the third phase in which patient lie flat for about 5 minutes with feet covered with a warm blanket before repeating the exercises .

C.Evaluation phase: After two weeks of performing Buerger Allen exercises for doing immediate post-test by using Tool II(ABI) scale and assessing wound healing through using Wagner Meggitt's classification of diabetic foot .

D. Follow up phase: After 4 weeks from intervention.

5. Results: The data collected were analyzed statistically and the results are categorized as following parts:

The demographic characteristics of the patients was shown in Table (5.1) at baseline; there were no statistically significant differences observed among study and control groups.

- Females were more prevalent in the sample than males. They constituted $(87.5 \%$ and $91.7 \%)$ for the study and 
Walaa El-khanany Zahran et. al.

control groups respectively .In relation to age, the majority of diabetic patients were between 40 to 60 years old. As regards marital status the majority of diabetic patients in both groups were married.

Regarding the educational level, the highest percentage of the studied diabetic patients were able to read and write. Concerning patient's occupation, it was observed that about three quarter of the studied diabetic patients were housewives. Regarding activity level, the results revealed that the highest percentage of the studied diabetic patients had both sedentary \& standing activity level, the reported percentage were $54.2 \%$ and $70.8 \%$ of the study and control groups respectively. It was found that the majority of diabetic patients in both groups reported family history of DM from first degree relativity.

Table (5.1): Distribution of studied groups according to their demographic characteristics.

\begin{tabular}{|c|c|c|c|c|c|c|}
\hline & \multicolumn{2}{|c|}{$\begin{array}{l}\text { Study } \\
(\mathbf{n}=\mathbf{2 4})\end{array}$} & \multicolumn{2}{|c|}{$\begin{array}{l}\text { Control } \\
(\mathrm{n}=24)\end{array}$} & \multirow[t]{2}{*}{$\square^{\square}$} & \multirow[t]{2}{*}{$\mathbf{p}$} \\
\hline & No & $\%$ & No. & $\%$ & & \\
\hline \multicolumn{7}{|l|}{ Gender } \\
\hline Male & 3 & 12.5 & 2 & 8.3 & \multirow[b]{2}{*}{$\square \square \square$} & \multirow{2}{*}{$\begin{array}{l}{ }^{\mathrm{FE}} \mathrm{p}= \\
1.000\end{array}$} \\
\hline Female & 21 & 87.5 & 22 & 91.7 & & \\
\hline \multicolumn{7}{|l|}{ Age } \\
\hline $20-<30$ & 0 & 0.0 & 0 & 0.0 & \multirow{4}{*}{3.038} & \multirow{4}{*}{$\begin{array}{l}{ }^{\mathrm{MC}} \mathrm{p}= \\
0.215\end{array}$} \\
\hline $30-<40$ & 2 & 8.3 & 0 & 0.0 & & \\
\hline $40-<50$ & 12 & 50.0 & 9 & 37.5 & & \\
\hline $50-60$ & 10 & 41.7 & 15 & 62.5 & & \\
\hline Mean \pm SD & \multicolumn{2}{|c|}{$47.83 \pm 5.91$} & \multicolumn{2}{|c|}{$50.38 \pm 5.19$} & $t=1.583$ & 0.120 \\
\hline \multicolumn{7}{|l|}{ Marital status } \\
\hline Married & 20 & 83.3 & 18 & 75.0 & \multirow{4}{*}{2.110} & \multirow{4}{*}{$\begin{array}{l}{ }^{\mathrm{MC}} \mathrm{p}= \\
0.644\end{array}$} \\
\hline Single & 0 & 0.0 & 1 & 4.2 & & \\
\hline Widow & 2 & 8.3 & 4 & 16.7 & & \\
\hline Divorced & 2 & 8.3 & 1 & 4.2 & & \\
\hline \multicolumn{7}{|l|}{ Level of education } \\
\hline Illiterate & 5 & 20.8 & 6 & 25.0 & \multirow{4}{*}{4.075} & \multirow{4}{*}{$\begin{array}{l}{ }^{\mathrm{MC}} \mathrm{p}= \\
0.209\end{array}$} \\
\hline Read and write & 16 & 66.7 & 10 & 41.7 & & \\
\hline Secondary education & 3 & 12.5 & 6 & 25.0 & & \\
\hline University education & 0 & 0.0 & 2 & 8.3 & & \\
\hline \multicolumn{7}{|l|}{ Occupation } \\
\hline Manual work & 2 & 8.3 & 1 & 4.2 & \multirow{4}{*}{3.353} & \multirow{4}{*}{$\begin{array}{l}{ }^{\mathrm{MC}} \mathrm{p}= \\
0.422\end{array}$} \\
\hline Employee & 2 & 8.3 & 6 & 25.0 & & \\
\hline House wife & 19 & 79.2 & 17 & 70.8 & & \\
\hline Retired & 1 & 4.2 & 0 & 0.0 & & \\
\hline \multicolumn{7}{|l|}{ Activity level } \\
\hline Sedentary & 9 & 37.5 & 2 & 8.3 & \multirow{3}{*}{$6.126^{*}$} & \multirow{3}{*}{$\begin{array}{c}{ }^{\mathrm{MC}} \mathrm{p}= \\
0.047^{*}\end{array}$} \\
\hline Standing & 2 & 8.3 & 5 & 20.8 & & \\
\hline Both sedentary \& standing & 13 & 54.2 & 17 & 70.8 & & \\
\hline \multicolumn{7}{|l|}{$\begin{array}{l}\text { Family history of diabetes } \\
\text { mellitus }\end{array}$} \\
\hline Yes & 21 & 87.5 & 24 & 100.0 & \multirow{2}{*}{3.200} & \multirow{2}{*}{$\begin{array}{l}{ }^{\mathrm{rE}} \mathrm{p}= \\
0.234\end{array}$} \\
\hline No & 3 & 12.5 & 0 & 0.0 & & \\
\hline Degree of relativity & $(\mathbf{n}=$ & & & & & \\
\hline First degree relative & 13 & 61.9 & 18 & 75.0 & & \\
\hline Second degree relative & 8 & 38.1 & 6 & 25.0 & 0.896 & 0.344 \\
\hline Third degree relative & 0 & 0.0 & 0 & 0.0 & & \\
\hline
\end{tabular}

$\chi^{2}, \mathrm{p}: \chi^{2}$ and $\mathrm{p}$ values for Chi square test for comparing between the two groups

$*$ : Statistically significant at $\mathrm{p} \leq 0.05$

${ }_{\mathrm{MC}} \mathrm{p}$ : $\mathrm{p}$ value for Monte Carlo for Chi square test for comparing between the two groups

${ }^{\mathrm{FE}} \mathrm{p}$ : : p value for Fisher Exact for Chi square test for comparing between the two groups 
Figure (5.1): Represent difference between studied groups through the study period as regard grades of diabetic foot ulcer. It can be observed from the figure that there is no statistically significant difference was observed between both groups before intervention $(\mathrm{MCp}=$ 0.831).In relation to study group, a statistical difference between pre, post and follow up grades of foot ulcer improvement, as grade 2 changed from( $20.8 \%)$ to reach $(12.5 \%$ and then $4.2 \%)$ in pre, post and follow up phases respectively and grade 1 from $(8.3 \%$ to $16.7 \%$ and changed to 12.5)as this difference become related to grade zero. After four weeks grade 0 changed from $70.8 \%$ in pre-test to reach $83.3 \%$ with healing ratio of $12.5 \%$. Compared with no changes in pre and immediate post-test of control group.

Figure (5.1): Difference between studied groups through the study period as regard grades of diabetic foot ulcer.

Table (5.2) : Comparison between studied groups according to ulcer surface area through the study period.

\begin{tabular}{|c|c|c|c|c|c|c|c|c|c|}
\hline & \multicolumn{2}{|c|}{ Pre-test } & \multirow[b]{2}{*}{$\mathbf{p}_{1}$} & \multicolumn{2}{|c|}{ immediate post-test } & \multirow[t]{2}{*}{$\mathbf{P}_{2}$} & \multicolumn{2}{|c|}{ follow up test } & \multirow[b]{2}{*}{$\mathbf{p}_{3}$} \\
\hline $\begin{array}{c}\text { Ulcer } \\
\text { surface } \\
\text { area }\end{array}$ & $\begin{array}{l}\text { Study } \\
(n=7)\end{array}$ & $\begin{array}{c}\text { Control } \\
(\mathbf{n}=9)\end{array}$ & & $\begin{array}{l}\text { Study } \\
(n=7)\end{array}$ & $\begin{array}{c}\text { Control } \\
(\mathbf{n}=9)\end{array}$ & & $\begin{array}{l}\text { Study } \\
(n=7)\end{array}$ & $\begin{array}{c}\text { Control } \\
(\mathbf{n}=9)\end{array}$ & \\
\hline $\begin{array}{c}\text { Mean } \pm \\
\text { SD. }\end{array}$ & $\begin{array}{c}4.30 \pm \\
3.94\end{array}$ & $\begin{array}{c}5.96 \pm \\
5.32\end{array}$ & $\begin{array}{l}0.5 \\
02\end{array}$ & $\begin{array}{c}2.48 \pm \\
2.15\end{array}$ & $\begin{array}{c}4.88 \pm \\
5.99\end{array}$ & $\begin{array}{l}0.3 \\
33\end{array}$ & $\begin{array}{c}0.54 \pm \\
0.71\end{array}$ & $\begin{array}{c}4.76 \pm \\
5.12\end{array}$ & $\begin{array}{c}0.03 \\
9^{*}\end{array}$ \\
\hline
\end{tabular}

p1: $\mathrm{p}$ value for Student $\mathrm{t}$-test for comparing between study and control group in before intervention $\mathrm{p} 2$ : $\mathrm{p}$ value for Student $\mathrm{t}$-test $\mathrm{t}$ for comparing between study and control group in after $2 \mathrm{nd}$ week p3: $\mathrm{p}$ value for Student t-test for comparing between study and control group in after 4th week $*$ : Statistically significant at $\mathrm{p} \leq 0.05$

Table (5.3) and Table (5.4) : show comparison between studied groups according to ABI through the study period, there was significant difference in mean ankle brachial index after performance of Buerger Allen exercise for the study group as it elevated from $(0.74 \pm 0.11)$ to $(0.85 \pm$ $0.08)$ in immediate post-test $(\mathrm{p}=<0.001)$ and changed to $(0.91 \pm 0.11$ )into follow up phase $(\mathrm{p}=<0.001)$ and between immediate post-test and follow up test $(\mathrm{p}=$
0.010) . Compared to $(0.73 \pm 0.10)$ for control group changed into $(0.71 \pm$ 0.09 and $0.76 \pm 0.08$ ) into post and follow up phases respectively. There was no significant difference between two studied groups at the beginning of the study ( $\mathrm{tp}=0.682)$ on the other side mean difference between them into immediate post-test and follow up test was high significant $(\mathrm{tp}=<0.001)$. 
Table (5.3) : Differences between studied groups according ABI through the study period.

\begin{tabular}{|c|c|c|c|c|c|c|}
\hline $\begin{array}{c}\text { Ankle Brachial } \\
\text { pressure Index } \\
\text { (ABPI) (mmHg) }\end{array}$ & Pre-test & $\begin{array}{c}\text { immediate } \\
\text { post-test }\end{array}$ & $\begin{array}{c}\text { follow up } \\
\text { test }\end{array}$ & $\mathbf{p}_{\mathbf{1}}$ & $\mathbf{p}_{\mathbf{2}}$ & $\mathbf{p}_{\mathbf{3}}$ \\
\cline { 2 - 7 } Study (n= 24) & $0.74 \pm 0.11$ & $0.85 \pm 0.08$ & $\begin{array}{c}0.91 \pm \\
0.11\end{array}$ & $<0.001^{*}$ & $<0.001^{*}$ & $0.010^{*}$ \\
\hline Control (n= 24) & $0.73 \pm 0.10$ & $0.71 \pm 0.09$ & $\begin{array}{c}0.76 \pm \\
0.08\end{array}$ & 0.129 & $0.041^{*}$ & $0.001^{*}$ \\
\hline
\end{tabular}

$\mathrm{p}: \mathrm{p}$ value for $\mathrm{F}$ test (ANOVA) with repeated measures

*: Statistically significant at $\mathrm{p} \leq 0.05$

p1: $\mathrm{p}$ value for comparing between Pre-test and immediate post-test with in same group p2: $p$ value for comparing between Pre-test and follow up test with in same group p3: p value for comparing between immediate post-test and follow up test with in same group

Table (5.4):Comparison between studied groups according ABI through the study period.

\begin{tabular}{|c|c|c|c|c|c|c|c|c|c|}
\hline \multirow{2}{*}{$\begin{array}{c}\text { Ankle } \\
\text { Brachial } \\
\text { pressure Index } \\
\text { (ABPI) } \\
\text { (mmHg) }\end{array}$} & \multicolumn{2}{|c|}{ pre-test } & \multirow[b]{2}{*}{ P1 } & \multicolumn{2}{|c|}{ immediate post-test } & \multirow[b]{2}{*}{ P2 } & \multicolumn{2}{|c|}{ follow up test } & \multirow[b]{2}{*}{ p3 } \\
\hline & $\begin{array}{l}\text { Study } \\
(n=24)\end{array}$ & $\begin{array}{c}\text { Control } \\
(n=24)\end{array}$ & & $\begin{array}{l}\text { Study } \\
(=24)\end{array}$ & $\begin{array}{c}\text { Control } \\
(n=24)\end{array}$ & & $\begin{array}{l}\text { Study } \\
(\mathrm{n}=24)\end{array}$ & $\begin{array}{c}\text { Control } \\
(n=24)\end{array}$ & \\
\hline Mean \pm SD & $0.74 \pm 0.11$ & $0.73 \pm 0.10$ & $\begin{array}{l}{ }^{\mathrm{t}} \mathrm{p}=0 . \\
682\end{array}$ & $\begin{array}{c}0.85 \pm \\
0.08\end{array}$ & $\begin{array}{c}0.71 \pm \\
0.09\end{array}$ & $\begin{array}{l}\mathrm{tp}=<0 \\
.001^{*}\end{array}$ & $\begin{array}{c}0.91 \pm \\
0.11\end{array}$ & $\begin{array}{c}0.76 \pm \\
0.08\end{array}$ & $\begin{array}{l}\mathrm{tp}=<0 \\
.001^{*}\end{array}$ \\
\hline
\end{tabular}

$\mathrm{t}, \mathrm{p}$ : $\mathrm{t}$ and $\mathrm{p}$ values for Student t-test

*: Statistically significant at $\mathrm{p} \leq 0.05$

$\mathrm{p}_{1}$ : $\mathrm{p}$ value for comparing between study and control group in before intervention

$\mathrm{p}_{2}$ : $\mathrm{p}$ value for comparing between study and control group in immediate post-test

$\mathrm{p}_{3}$ : $\mathrm{p}$ value for comparing between study and control group in follow up test

Figure (5. 2 ): illustrate lower extremity perfusion improvement among studied groups through the study period. There was no significant difference between two studied groups at the beginning of the study. But there was significant difference between them after performance of Buerger Allen exercise. In relation to study group, a statistical difference between pre, post and follow up where level of impairment improved to reach $41.7 \%$ normal lower extremity perfusion in immediate post-test and $58.3 \%$ in follow up test. Compared with no noticeable change in control group.

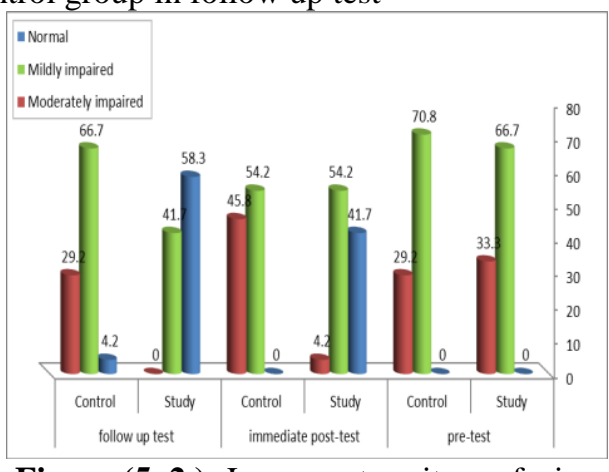

Figure (5. 2 ): Lower extremity perfusion improvement among studied groups through the study period.

\begin{tabular}{|c|c|c|}
\hline $\begin{array}{r}\text { Normal lower extremity } \\
\text { perfusion (ABI): Above } 0.9\end{array}$ & $\begin{array}{lr}\text { Obstruction(ABI):0.71 } & \text { Mild } \\
0.90\end{array}$ & $\begin{array}{rr}\text { Moderate } & \text { obstruction } \\
(\mathrm{ABI}): 0.41-0.70\end{array}$ \\
\hline
\end{tabular}


Table (5.5) and Figure (5.3 ,5.4 and 5.5): Demonstrate the correlation between patient's ABI with Ulcer surface area through the study period for study group. As observed, there was a significant negative correlation between patient's ABI and ulcer surface area before and after performing Buerger Allen exercises where $p$ values were found to be $(p=0.027)$ in Pre-test and ( $p=0.035)$ in immediate posttest. But, this correlation was not significant in follow up where ( $\mathrm{p}=0.144)$.

Table (5.5): Correlation between patient's ABI with Ulcer surface area through the study period for study group.

\begin{tabular}{|c|c|c|c|}
\hline \multirow{5}{*}{ 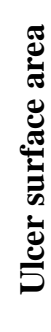 } & \multicolumn{3}{|c|}{ ABI } \\
\hline & & $\mathbf{r}$ & $\mathbf{P}$ \\
\hline & Pre-test & $-0.809^{*}$ & $0.027^{*}$ \\
\hline & $\begin{array}{l}\text { Immediate } \\
\text { post-test }\end{array}$ & $-0.789^{*}$ & $0.035^{*}$ \\
\hline & $\begin{array}{l}\text { Follow up } \\
\text { test }\end{array}$ & -0.612 & 0.144 \\
\hline
\end{tabular}

r: Pearson coefficient

*: Statistically significant at $\mathrm{p} \leq 0.05$ ABI : Ankle Brachial Index

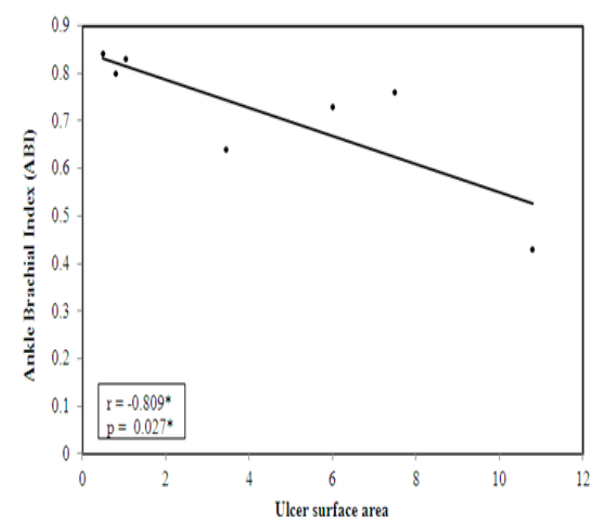

Figure (5.3):Correlation between $\mathrm{ABI}$ and Ulcer surface area in pre-test

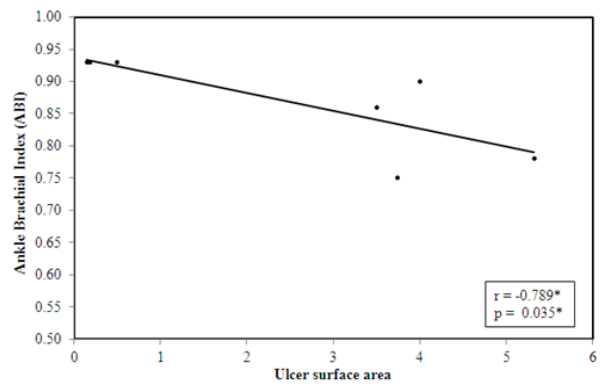

Figure (5.4):Correlation between $\mathrm{ABI}$ and Ulcer surface area in immediate post-test.

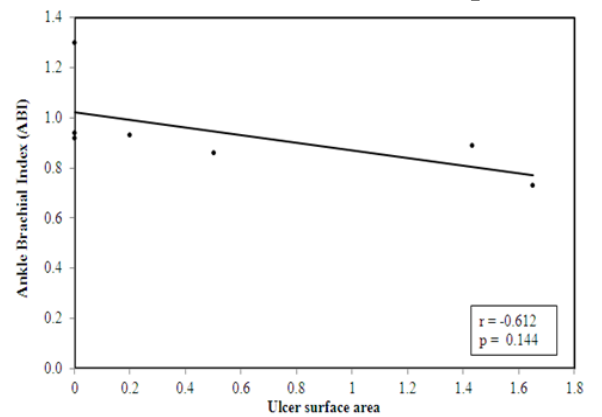

Figure (5.5):Correlation between $\mathrm{ABI}$ and Ulcer surface area in follow up test6-

\section{Discussion}

Foot problems in diabetic patients remain a major public health problem and are the most common reason for hospitalization of patients with diabetes with prevalence as high as $25 \%$. This high prevalence lead to significant clinical and economic impact ${ }^{(14)}$. Peripheral arterial disease is estimated to be 2 to 4 times more common in persons with diabetes than in others which increase the risk for amputation ${ }^{(\mathbf{1 5})}$. Increasing foot peripheral circulation in patients with diabetes is important not only in relieving symptom , but also in prevention of ulcer and amputation. Buerger Allen exercise intended to improve feet and legs circulation, relieve the symptoms in patients with lower limbs arterial insufficiency, It drained engorged vessels by using postural changes and applying 
muscle contractions to stimulate peripheral circulation $^{(\mathbf{1 0})}$.

The results of the present study revealed that, females were more prevalent in the sample than males, the same results reported by Fouad ,2009; Tavintharan et al,2009 $\left.{ }^{(16,17}\right)$. As regard to age the majority of studied groups were between forty and sixty years old, this in the same line with Hassan \& Mehani, 2012 ${ }^{(\mathbf{1 8})}$, this finding may be due to that PAD is chronic complications of D.M that require years to occur, so it appear in older adult who have diabetes since several years.

It was observed that the highest percentage of the studied diabetic patients had both sedentary \& standing activity level, this result in the same line with John \& Rathiga, $2015^{(19)}$. In relation to length of time since diagnosis, it is noticed that, the largest proportion of the studied groups had diabetes mellitus for more than 10 years, this finding in agreement with Coce, Metelko, Jaksic, Car, \& Pavkovic, 2008 ${ }^{(20)}$ and this finding may be due to chronicity of the disease.

Regarding hypertension it was observed that the majority the studied groups were hypertensive, this finding in agreement with C. Chang, Chang, Hwang, \& Chen, $2015^{(21)}$; this finding may be due to the fact that hypertension and DM are interrelated.

When assessing wound size and grades among the study group, our study revealed that continuous improvement along the study period from pre-test to immediate post-test and then in follow up in which there is a percentage of study group achieve wound healing and shown no break in the skin test. In comparison of control group, there was slow healing process as wound size and depth show no significant difference from pre-test to immediate post-test and follow up test , these results is in accordance with Vijayabarathi, 2016;Vijayabarathi \&
Hemavathy, 2014 ${ }^{(22,23)}$ who stated that grade and size of wound highly decrease in study group from pre -test to post-test and patients had been showed better wound healing compared to control group and this finding is due to that Buerger Allen exercise which help to improve the vascularization of lower limbs and consequently it will help to improve the wound healing process.

Concerning lower extremity perfusion, it was noted that the study group show significant improvement along the study period as level of lower limb impairment improved to reach nearly half of patients with normal lower extremity perfusion in immediate post-test and more than half normal perfusion in follow up test. Compared with control group there was not significant change in level of lower extremity perfusion impairment from beginning to the end of the study. This result in the same line with Mellisha, 2016 (24). This finding is due to doing Buerger Allen exercise which use gravity to empty and fill blood vessels alternately to drain congested vessels, which finally improves blood transportation, stimulate and promote collateral circulation.

The same finding show positive relation between body mass index(BMI) and patients' ABI. Which were more worse in patients who have higher BMI these results come in line with Subramaniam et al., $2011{ }^{(25)}$. This finding may be due to that obesity is a major risk factor for PAD.As regard correlation between patient's ABI and Ulcer surface area, the present study showed significant negative correlation between patient's ABI and ulcer surface area before and after performing Buerger Allen exercises. The same results reported by Vijayabarathi, 2016; Vijayabarathi \& Hemavathy, 2014 $(22,23)$. This is may be due Burger Allen exercises which improve vascularity to lower limbs and consequently it will help 
EFFECT OF BUERGER ALLEN EXERCISE etc...

to improve perfusion and wound healing process simultaneously.

7- Conclusion: The results of the current study proved that Buerger Allen exercise was found to be effective on improving the lower extremity perfusion among patients with type 2 diabetes mellitus . On the other hand, diabetic foot ulcer patients can adopt Buerger Allen exercise to promote faster wound healing.

8-Recommendations:In the light of the results of the present study, the following recommendations are suggested:

For patients:

- Organizing patient's centered workshops to teach about diabetes mellitus disease, it's harmful complications especially on lower limb and to how to perform Burger Allen exercise to avoid or decrease these complication.

For health care providers:

- An educational program should be applied about Burger Allen exercise for all nurses working in medical unit (inpatient \&outpatient) to provide them with the necessary and required knowledge and skills.

9-Acknowledgments:Thanks to Specialized-Medical Hospital and all the individuals who accepted and participated in this study

\section{0- Reference:}

1. Danaei, G., Finucane, M. ., Lu, Y., Singh, G., Cowan, M., Paciorek, C., ... Ezzati, M. (2011). National, regional, and global trends in fasting plasma glucose and diabetes prevalence since 1980: Systematic analysis of health examination surveys and epidemiological studies with 370 country-years and 2.7 million participants. The Lancet, 378(9785), 31-40. http://doi.org/10.1016/S01406736(11)60679-X.
2. International Diabetes Federation. (2015). IDF Diabetes Atlas, 7th ed. Brussels, Belgium: International Diabetes Federation, 2015. http://www.diabetesatlas.org.

3. Canadian Diabetes Association Clinical Practice Guidelines expert committee. (2013). Clinical Practice Guidelines for the Prevention and Management of Diabetes in Canada. Can J Diabetes, 37 (supp 1), S1-S212.

4. World Health Organization. (2016). Global Report on Diabetes, 88. http://doi.org/ISBN978 9241565257.

5. Board, I. E. (2015). The 2015 International Working Group on the Diabetic Foot (IWGDF) Guidance documents on prevention and management of foot problems in diabetes: development of an evidence-based global consensus on the Diabetic Foot The 2015 IWGDF Guidance documents on prevention and management of foot problems in diabetes.

6. Chawla, R. (2012).Complications of Diabetes1ST ed.; Foot Complications in Diabetes. New Delhi ,Panama City ,London : Jaypee Brothers Medical Publishers Pvt. Ltd. P;82-90

7. Poretsky,L., Liao,E., LeRoith,D. (2014). Diabetes Mellitus: Associated Conditions, An Issue of Endocrinology and Metabolism Clinics of North America, Peripheral Arterial Disease. USA, New York: Elsevier Inc., 43(1) ISSN 0889-8529, ISBN 13: 978-0-323-28704-3. $\mathrm{P} ; 149-152$

8. Berry, T.A., Johnson, S.A., and Sommers, M.S., (2007). Arterial Occlusive Disease. In: Diseases \& Disorders: A Nursing Therapeutics Manual, 3rd Ed, F.A. Davis Company, Philadelphia, 102-106.

9. Conti,A.,Gensini, G., \& Macchi, C. (2007). Relationship between Physical Activity and Cardiovascular Disease: 
Selected Historical Highlights. The Journal of Sports Medicine and Physical Fitness, 47, 84-90.

10. Chang,C.-C., Chen, M.-Y., Shen, J.H., Lin, Y.-B., Hsu, W.-W., \& Lin, B.-S. (2016). A quantitative real-time assessment of Buerger exercise on dorsal foot peripheral skin circulation in patients with diabetes foot. Medicine, 95(46), e5334.

11. Aruna, S., \& Thenmozhi, P. (2015). Effectiveness of allen buerger exercise in preventing peripheral arterial disease among people with type II diabetes mellitus. International Journal of Pharma and Bio Sciences, 6(2), B966-B970.

12. Grenon, S., Chong, K., Alley, H., Nosova, E., Gasper, W., Hiramoto, J., ... Owens, C. (2014). Walking disability in patients with peripheral artery disease is associated with arterial endothelial function. Journal of Vascular Surgery, 59(4), 10251034.

http://doi.org/10.1016/j.jvs.2013.10.0 84.

13. Park, C., Koehler, K., Romero, S., Windle, M., \& Peter, K. (2016).The heart.org Medscape. Ankle-Brachial Index Measurement. Retrieved May 5, 2017 , from http://emedicine.medscape.com/article /1839449-overview\#a3 Chan

14. Sumpio, B. E. (2012). Contemporary Evaluation and Management of the Diabetic Foot. Scientifica, 2012, 435487. http://doi.org/10.6064/2012/435487.

15. Shrikhande,G,V.,McKinsey,J,F.,(2012 ) .Diabetes and peripheral vascular disease .diabetic foot ulceration and management. USA, New York: Springer Science \& Business Media. Humana Press .ISBN:978-1-62703158-5. p,63-91.

16. Fouad ,R.A. (2009).Common Foot Health Problems and Measures to
Prevent It among Diabetic Geriatric Patients. Journal of the Medical Research Institute (MRI); 30.2: (11827).

17. Tavintharan S., Cheung N, Su C., Tay W., Shankar A., Shyong T., Wong T. (2009). Prevalence and risk factors for peripheral artery disease in an Asian population with diabetes mellitus. Diab Vasc Dis Res 2009; 6(2): 80-6.

18. Hassan, S., \& Mehani, M. (2012). Comparison between Two Vascular Rehabilitation Training Programs for Patients with Intermittent Claudication as a Result of Diabetic Atherosclerosis. Bull. Fac. Ph. Th. Cairo Univ., 17(1), 7-16.

19. John, J., \& Rathiga, A. (2015).. International Journal of Current Research and Academic Review, 3(4), 358-366. Retrieved from http://www.ijcrar.com/archive-20.php

20. Coce, F., Metelko, Z., Jaksic, B., Car, N., \& Pavkovic, P. (2008). Peripheral arterial disease and diabetes mellitus. Diabetologia Croatica, 37(2), 47-53

21. Chang, C., Chang, C., Hwang, S., \& Chen, M.-Y. (2015). Effects of Buerger Exercise Combined HealthPromoting Program on Peripheral Neurovasculopathy Among Community Residents at High Risk for Diabetic Foot Ulceration. Worldviews on Evidence-Based Nursing, 12(3), 145-153.

22. Vijayabarathi, M. (2016). A Study To Assess The Effectiveness of Buerger Allen Exercise on Wound Healing Process among the Diabetic Foot Ulcer Patients. Int J Pharm Bio Sci, 7(3), 1253-1257.

23. Vijayabarathi, M., \& Hemavathy, V. (2014). Buerger Allen Exercise for Type 2 Diabetes Mellitus Foot Ulcer Patients. International Journal of Innovative Research in Science, 
Engineering and Technology, 3(12), 17972-17976.

24. Mellisha, E. S. (2016). Effectiveness of Buerger Allen Exercise on Lower Extremity Perfusion and Pain among Patients with Type 2 Diabetes Mellitus in Selected Hospitals in Chennai. International Journal of Science and Research (IJSR), 5(7), 1822-1826.
25. Subramaniam, T., Nang, E., Lim, S., Wu, Y., Khoo, C., Lee, J., ... Tai, E. S. (2011). Distribution of ankle-brachial index and the risk factors of peripheral artery disease in a multiethnic Asian population. Vascular Medicine (London, England), 16(2), 87-95.

http://doi.org/10.1177/1358863X1140 $\underline{0781}$ 